\title{
EVIDENCE BASED PRACTICE
}

*Mrs. K.Kalpana Ramesh

\section{Introduction:}

Roots of Evidence based practice $(\mathrm{EBO})$ can be traced in "Florence "Nightingales" Era of Nursing practice. Her concepts promoting health prevention of disease and care of the sick were central ideas of her system. It involves identifying soild research findings and implementing them in nursing practices, in order to increase the quality of patient care. The terms research utilization and EBP are used interchangeably.

\section{DEFINITIONS:}

\section{Evidence based practice (EBP):}

EBP as using the best evidence available to guide clinical decision making. This definition shift the provision of health care away from past practices and precedent towards a more scientific basis.

\section{Evidence based Nursing (EBP) :}

EBN may be defined as the conscientious explicit and judicious use of current best evidence in making decision about the evidence individual patients or groups. It requires integration of individual clinical expertise and patient preference with the best available external clinical evidence from systematic research and consideration of available resources.

\section{Research utilization (RU)}

Research utilization is the process of communication and using research generated knowledge to make an impact on or a change in the existing practices in the health care systems.

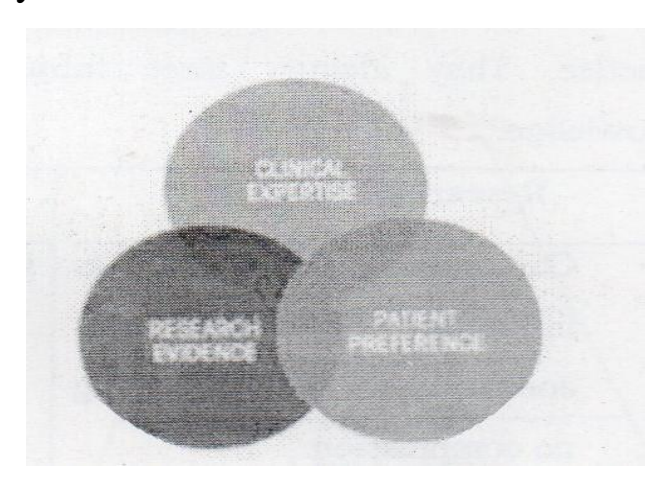




\section{Three components of EBP:}

- Research evidence

- Clinical expertise.

- Patient preference.

\section{Research finding as evidence}

Evidence provided from a single research study is generally considered insufficient grounds to justify changing practice. Rather a body of research evidence on a particular topic needs to be established. Ideally a systematic review of relevant research should be undertaken in order to draw an overall conclusion about the cumulative evidence.

\section{Professional expertise as evidence}

Recent research has highlighted the extent to which nurses draw upon the knowledge gained experientially in the work place. for example from specialist nurses, members of the multidisciplinary team and professional network.

The knowledge that nurses use within the content of evidence basrd practice. They identify three forms of knowledge.

\section{Patient experience as evidence}

The nurses should share their knowledge of research findings underpinning clinical interventions with patients so that patients understand the appropriateness of the intervention and can exercise an informed choice when there are alternative courses of action available.

\begin{tabular}{|c|c|c|}
\hline Research Evidence & Clinical Expertise & Patient preference \\
\hline $\begin{array}{l}\text { Compression } \\
\text { bandaging has } \\
\text { improved healing } \\
\text { rates compared to } \\
\text { treatment using no } \\
\text { compression. }\end{array}$ & $\begin{array}{l}\text { Knowledgeable of benefices } \\
\text { of compression bandaging. } \\
\text { technique offered. }\end{array}$ \\
\hline $\begin{array}{l}\text { Compression } \\
\text { therapy is more } \\
\text { cost-effective }\end{array}$ & $\begin{array}{l}\text { Trained in applying } \\
\text { compression bandaging. }\end{array}$ & $\begin{array}{l}\text { Willingness to comply } \\
\text { with treatment regime. }\end{array}$ \\
\hline
\end{tabular}




\begin{tabular}{|c|c|c|c|}
\hline & $\begin{array}{l}\text { because the faster } \\
\text { healing rates saved } \\
\text { nurse time. }\end{array}$ & & \\
\hline & $\begin{array}{l}\text { High compression } \\
\text { achieves better } \\
\text { healing rates than } \\
\text { low compression. }\end{array}$ & $\begin{array}{l}\text { Skilled patient education to } \\
\text { promote patient } \\
\text { understanding of leg ulcer } \\
\text { management }\end{array}$ & $\begin{array}{l}\text { Experience of other } \\
\text { treatment programmes. }\end{array}$ \\
\hline 4 & $\begin{array}{l}\text { Multi layer } \\
\text { compression } \\
\text { systems are more } \\
\text { effective than single } \\
\text { layer system }\end{array}$ & $\begin{array}{l}\text { Concordance with treatment } \\
\text { regime. }\end{array}$ & \\
\hline
\end{tabular}

\section{Hierarchies of evidence}

Hierarchies of evidence have played an important role in guiding the systematic reviews undertaken by the National centre for Research and Dissemination and in informing the guidance produced by the National Institute for Health and Clinical Excellence.(NICE).

It shows a 7 level hierarch that has at its pinnacle systematic reviews of Randomized Clinical Trails. (RCT) The strongest evidence according to

this hierarchy comes from systematic reviews that integrate finding from multiple RCT studies using rigorous and methodical procedures. Systematic reviews of non randomized clinical trials are less powerful evidence. At the bottom of this evidence hierarchy are opinions from experts.

\section{Level -I}

a. Systematic reviews of RCT

b. Systematic reviews of non Randomized trials

\section{Level -II}

a. Single RCT

b. Single non nonradomizes trial

\section{Level -III}

Systematic review of cor relational / observational studies
Level -IV 
Single correlation observation study

Level - V

Systematic review of descriptive / qualitative study

\section{Level - VI}

Single description qualitative physiologic study

\section{Level -VII}

Opinions of authorities expert committees

\section{Hierarchies of evidence}

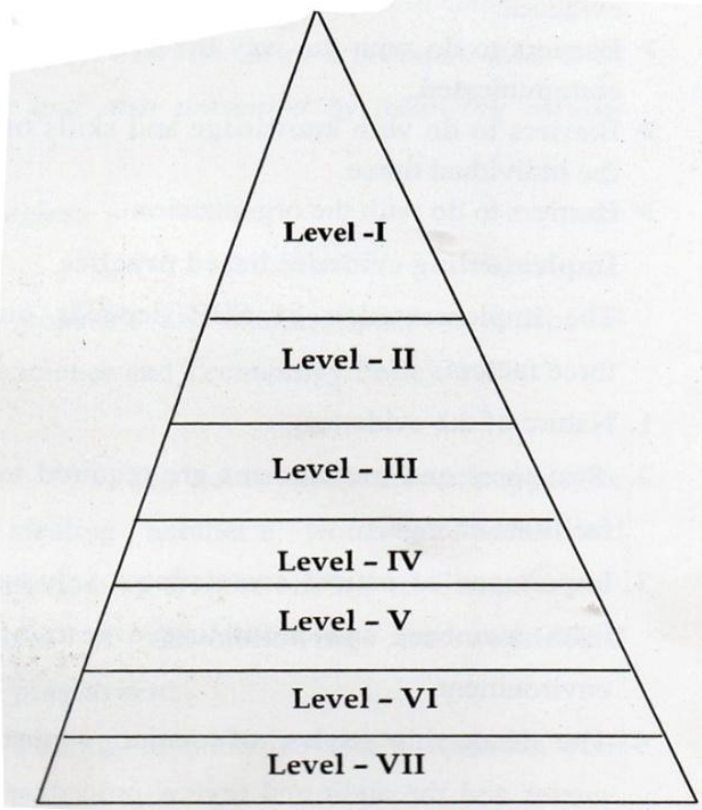

Resources for Evidence Based Practice:

1. Systematic Reviews.

2. Clinical practice guidelines

3. Other pre appraised evidence
The stages of evidence based practice

1. Identify a problem or issues from practice

2. Formulate an answerable question.

3. Identify an available evidence

4. Appraise the evidence

5. Develop guidance for practice.

6. Plan strategy for introducing changes.

7. Implement changes.

8. Evaluate the impact of change.

\section{Barriers to achieving evidence based practice:}

$>$ Barriers to do with the nature of the evidence.

$>$ Barriers to do with the way the evidence is communicated.

$>$ Barriers to do with knowledge and skills of the individual nurse.

Barriers to do with the organization.

\section{Implementing evidence based practice}

The implementation of EBP depends on three factors,

1. Nature of the evidence.

2. Structures and mechanisms are required to facilitate change.

3. Importance of patient centeredness valuing team members and promoting a learning environment. 
4. The leadership styles of senior clinical nurses and the audit review procedures in place.

\section{Conclusion}

Achieving evidence based practice is a complex undertaking that involves identifying and appraising different sources of evidence translating evidence into clear guidance for practice, implementing change and finally evaluating the impact of change.

\section{Bibliography}

1. Nancy burns, susan K.Grove, "Understanding nursing research", II edition Saunderscompany, New Delhi, (2002) Page No: 418-450.

2. Suresh K.Sharma, "Nursing Research and statistics, II edition Elsevier, India privete limited,
New Delhi, (2014) Page No : 2933.

3. Kate Gerrish and Anne lacey, "The Research process in nursing " $5^{\text {th }} \quad$ Edition Blackwell publishing, (2006), Page No:491519.

4. Denise F.Polit, and Cheryl tatano beck, Nursing Research generating and assessing Evidence for Nursing practice, $8^{\text {th }}$ Edition, (2008), Lippincott, williams and wilkins, London Page No:664-691.

5. Mckenna.H, et.al., Barriers to evidence based practice in primary care, (2004), Journal of advanced Nursing, Page No:178179. 